\title{
Political Leadership during a Policy Shift: The Effort to Revise the Sejong City Plan
}

\author{
Dalgon Lee*
}

\begin{abstract}
To promote a controversial policy, a leader must find factors that are favorable to change, and neutralize (or minimize) the opposition to it. In advocating the revised Sejong City plan, the government, including the president, the prime minister, and an advisory panel, encountered deep-rooted oppositioninitially from a minority within the ruling party, and then from residents of Chung-cheong Province and the opposition parties. The prime minister's abrupt approach, without prior consultation with ruling party members, and his desperate yet hasty attempt to expand a policy coalition, was not able to reconcile the differences in this case. Incentives for opposing groups were not well established. The ruling party's defeat in local elections made it even more difficult to move forward with the revised plan. Cognition theory, in particular a simplified version of Howard Gardner's concept of seven levers for changing minds, provides a useful analytical tool for understanding this case.
\end{abstract}

Keywords: policy leadership, Sejong City, policy revision, changing minds

\section{INTRODUCTION}

Policy evolution usually involves incremental changes. If there is an abrupt policy change, with dramatic and radical changes both of direction and contents, leaders must act carefully to reduce friction and change the minds of the involved parties. Extensive political mobilization and coalition building are often required, especially in decentralizing democracy, to overcome entrenched interests. Policy entrepreneurs should create a dynamic between the politics of subsystems and the macropolitics of the legislature and the presidency (James et. al., 1999).

When members of a heterogeneous populace attempt to maximize their own benefits, political leadership should be skillfully exercised in relation to politicians, interest

* Dalgon Lee is chair and professor at Kyungwon University. This paper was supported by the Kyungwon University Research Fund in 2011.

Manuscript received February 10, 2011; out for review February 28, 2011; review completed March 18, 2011; accepted April 20, 2011.

The Korean Journal of Policy Studies, Vol. 26, No. 1 (2011), pp. 1-19.

(C) 2011 by the GSPA, Seoul National University 
groups, and the diverse residents of different provinces. The complex system of overlapping authority, the multiple motivations of political actors, and the myriad of groups with a variety of political identities create opportunities for political entrepreneurship (Fuchs, 2010, pp. 70-75). But leaders must find the factors that will impel people to change their minds, and must not underestimate the opposition. Their approach must be creative, well designed and planned, and executed skillfully in a step-by-step process in order to reduce opposition and nurture a growing coalition of supporters.

This article analyzes the prime minister's role in the revised Sejong City plan, within a theoretical frame of cognitive leadership based on a simplified version of Gardner's seven "levers" for changing minds.

\section{BACKGROUND}

\section{Original Plan}

The Roh Moo-hyun government (2003-2008) devised an ambitious plan in 2003 to relocate the capital to a small, newly built city in Chung-cheong Province as the centerpiece of his administration. But the Constitutional Court ruled in October 2004 that the relocation was unconstitutional, because the Constitution refers to Seoul as the capital of Korea. The Roh administration then created an alternative plan to construct a multifunctional administrative city, in which nine major ministries and four agencies would be relocated from Seoul to nearby Kwachoen City. This political swing region continued to claim that the construction of the administrative city should be carried out as it was mentioned in the original plan, whenever anyone called for revision. The new city was expected to have more than 500,000 residents by 2030 .

\section{Revision Attempts}

During the 2007 presidential campaign, Lee Myung-bak pledged to follow through with the former government's original plan for an administrative city. He changed course after he was elected and even said that he was ashamed of having backed the project during the campaign.

After the election, the president's office researched alternatives that would allow the new city to operate self-sufficiently without causing inefficiencies in government. In a report to the president on July 21, 2008, the National Balanced Development Commission raised the need for institutional arrangements and strong incentives in 
order to build a self-sufficient city at the designated location. When Chung Un-chan was appointed prime minister on September 3, 2009, he mentioned the inefficiencies of the city and said that the original plan would not be executed.

On November 4, 2009, the prime minister proposed to turn the plan into an economically viable city based on education, science, and industry. The government established a joint government-civilian advisory panel on Sejong City (hereafter referred to as the Joint Panel), co-chaired by the prime minister. On January 8, 2010, the president said that the government and the ruling party should push ahead with the revised Sejong City plan. On January 11, the government officially scrapped the initial plan, and the prime minister announced a new master plan, devised by the Joint Panel, to build an economically self-sufficient city focusing on education and science, in close partnership with leading businesses and educational institutions (Office of the Prime Minister, 2010).

The government offered incentives for local and foreign firms, as well as universities, to move into the city, including additional apartments, job training, community facilities, and cheaper farmland. Several conglomerates had plans to invest trillions: Samsung, Hanwha, Lotte, Woongjin, and Austria's SSF agreed to build new production, research, or business facilities. KAIST and Korea University also had plans to extend their research facilities and set up graduate schools in the city. And a global science business belt was going to be established along the ring of the city. The new master plan called for Sejong City to become a mecca of science and technology, with a population of 500,000, and for total investment to reach 8 trillion won by 2020 , creating 250,000 jobs.

\section{Political Struggle}

The announcement touched off immediate and intense conflict within the ruling party and drew a strong backlash from the opposition parties, especially from the Liberal Forward Party, whose support base is in the Chung-cheong area. Residents of the region protested immediately. To make matters worse, the government's offer of incentives to prospective investors and immigrant institutions, such as low land prices and reduced taxes, provoked opposition from other provinces that had been competing to attract industry and business.

The prime minister succeeded in making his point to the nation. And his approach could be considered normal strategic political behavior in the Korean cultural patrimony. But conflict expanded beyond the Joint Panel's anticipation. Park Geun-hye, former leader of the Grand National Party (GNP), lost no time in firmly rejecting the government's new plan, and she launched a direct political challenge to the president 
and the prime minister. In addition, the main opposition Democratic Party, which had 87 seats, and the conservative Liberal Forward Party, which had 18 seats, were determined to terminate the revised plan. Its chance of passing in the National Assembly seemed slim.

The government announced the revised plan bill on January 27, 2010, and submitted it to the National Assembly on March 23. Politicians wrangled over the issue, creating alternative plans and inventing consensus-building methods, until it died. Various alternative development plans were proposed, as well as the idea of a national referendum and the dismissal of the prime minister. The mass media covered the debate, in the legislature and among civil groups, thoroughly.

Within the ruling party, several compromise plans, including relocation of several other government ministries, were proposed. Those proposals acknowledged the difficulties of relocating the many ministries and agencies mentioned in the original plan and suggested, instead, relocating the judicial branch and related institutions, and ministries related to education, science, agriculture, and the environment.

The idea of putting the plan to a national referendum gained momentum within the ruling party. Ruling party leaders were fully aware that the chances of passing the new plan in the Assembly were low, given pro-Park legislators' opposition. Opposition parties, meanwhile, threatened to submit a motion to oust the prime minister to the Assembly, refusing to accept the proposal for a referendum. In the end, the ruling party did not move forward with the referendum, because it failed to get the president's support.

Different options were suggested regarding the decision-making method-for example, to postpone it until the general election of 2012, in order to hand the plan over to the next government. But a general meeting of all members of the ruling party failed to come up with a conclusive alternative to the government bill. The prime minister was struggling to make a breakthrough at this point. He visited Chung-cheong Province 13 times to visit the proposed city site, talk with residents and local leaders, and conduct interviews with the local press. The Joint Panel made every effort to promote the merits of the new plan. The issue was the top priority on the national agenda until the sinking of the battleship Chunan on March 26, 2010.

In the local elections held on June 3, 2010, none of the candidates in the Chungcheong region who supported the revised plan were elected. From a nationwide point of view, this was a severe defeat for the ruling party, and it affected the fate of the revision plan. On June 29, 2010, lawmakers voted down the revision bill 164-105, reinstating the original plan. About 50 followers of Park's faction voted against the revised plan, along with members of the opposing parties. 


\section{METHODOLOGY}

\section{Scope}

This article focuses on the political leadership of policy change-in particular, the interaction between the prime minister, who exercised such leadership, politicians who dealt with the issue, and members of the public. Because the political leadership came from the prime minister, empowered by the president, he is assumed to be the initiator of policy change - that is, a policy entrepreneur - and his actions, rather than the specific details of the plans or the political calculus of other, indirectly involved actorsare the focus of this article.

The traditional study of political leadership deals with two perspectives: the accomplishments of leaders, and the institutional and social constraints in the exercise of leadership (Jones, 1989, p. 3). The latter perspective was adapted to analyze this case, with emphasis on the mental process involved in exercising leadership, and the institutional and social context within which a leader operates and which determines much of his or her ability to portray or transform policy issues in the most advantageous way.

At the risk of oversimplification, it can be said that transforming leadership depends on the social environment, institutions (or structures), and the political skills of the leader. In order to change public policy in a given context, a policy leader must change the alignment of structures and institutions, and the minds of relevant elites and the general public. When a leader cannot realign structures, then the last resort is to change minds. The leadership theory of cognitive psychology offers insights into the process of transforming key politicians' minds and changing opinions in a heterogeneous constituency.

\section{Methods}

The political process is influenced by many material factors, but its prime locus is in the mind. It is a mental process in which leaders define a problematic situation, make a decision about how to deal with it, and appeal for a positive response to their new policy (Tucker, 1995, pp. 59-61). Leadership's task is to sway the minds of ordinary people as well as major policy participants toward acceptance of its proposal.

In the case of Sejong City, from the perspective of the change agent (the prime minister), there are three layers of participants: politicians, the residents of the Chungcheong region, and the general public. A leader must choose which issues to push and how to push them. According to cognitive psychology, the exercise of leadership is 
based on an emerging scientific understanding of how the mind works, how people change the minds of others as well as their own minds, and how they envision new scenarios and work to achieve them.

Based on historical cases, Gardner (2004) identified seven mind-changing "levers": reason, research, resonance, representational redescriptions, resources and rewards, real-world events, and resistances. This theoretical framework seems well suited to describing political leadership in general and the Sejong City debate in particular. But some modifications are needed to enhance their explanatory power in this specific case.

As discussed above, the leadership began advocating its agenda for Sejong City as the prime minister took office, there were three target groups, and the policy targeted for change had been a politically sensitive issue for several years. Therefore, modifying Gardner's levers to emphasize the process aspect-by combining reason and research into one category, rational argumentation - can provide a more comprehensive analysis.

Because a new leader entered the stage and attempted to drastically change a policy that had been a troublesome issue and the focus of tumult and strenuous effort, the exercise of leadership has unique features in this case. So the author added process management aspects of policy change to each lever. Strategies for raising the issue, shaping the terms of debate, and choosing the timing and sequence of building up a coalition and networking in political circles were crucial for striking a resonant chord with the policy audience and reducing resistance. Drastic change is sure to invite resistance. A policy entrepreneur cannot completely overcome protracted resistance, so the process must be skillfully managed in an effort to subdue or evade opposition.

The analytical framework for this study could be described as follows:

\section{Three layers of participants-}

1. Politicians

2. Local residents

3. General population

Six levers for changing minds-

1. Rational argumentation

2. Resonance

3. Representational redescription

4. Resources and rewards

5. Real-world events

6. Resistance 
In this case, especially, the aspect of resistance should be considered carefully in dealing with other relevant levers, because the policy had already been established in the form of a specific law, and the early stage of implementation was underway. Mind changing is unlikely to occur when resistance is stronger than motives for change.

From the prime minister's point of view, it was necessary to exercise leadership, involving the six levers listed above, with the three layers or target groups. Conceptually, once politicians, including members of both the ruling party and opposition parties, have been persuaded, it then becomes necessary to persuade the residents of Chungcheong Province — or this might even be done simultaneously. Then, the prime minister must acquire the consent of the general population. Different leadership activities can be carried out simultaneously, but swaying the minds of people in all three target groups is essential.

\section{ANALYSIS}

\section{Rational Argumentation}

Reason and research, as explained by Gardner, appeal to the cognitive aspects of the human mind. When a political leader laid out the problems and weaknesses of the original plan and presented his alternative solution to those problems, there was a chance that the minds of politicians, interest groups, and fellow citizens might be swayed by his appeal. But before anything else, through arguments and debates, he must acquire reasonable support for the revised plan, prepared as a scientific and logical endeavor, among the members of the ruling party.

While the original plan took the view that decentralization could be realized through relocation of official government buildings to Sejong City, the new plan considered that this would create inefficiencies and the city would not prosper or become self-sufficient. The prime minister attempted to frame the policy issue in relation to the economy, which was his major playing field, believing that this would be an effective way of appealing to diverse interests in the region.

The Joint Panel devised a new plan for an economically focused, market-oriented city instead of a power-oriented administrative center. Educational institutions would bring in young students, brilliant researchers, and other developmental facilities. In addition, investments by conglomerates and foreign enterprises would produce a new growth engine that would generate jobs and attract more residents, making the city self-sufficient.

This was markedly different from the original plan: there would be no government 
agencies; instead, the city would become a hub for the knowledge industry. The Joint Panel did not hint that the possibility of moving several government agencies was still open and that those new arrangements could be made in the process of the legislative deliberation. Actually, several members of the ruling party proposed an alternative revised plan when they spoke in the National Assembly, which included relocation of several education- and science-related agencies or judicial institutions. But the government did not respond carefully to such proposals. It stuck to the principle that any separation of the executive branch would result in huge inefficiencies, and did not consider relocation of even a small number of government agencies.

If the Joint Panel had carefully assessed the turbulent waters of intra-party politics and the cohesion of opposing groups, it could have considered moving some government offices. A sensible combination of government buildings, relocation of institutions, and market-oriented investments could have made it possible to overcome opposition to the plan.

In politics, it is sometimes necessary to emphasize features of a policy other than its substantive merits. The new plan was composed of diverse components needed for a city to grow. But core features, like the concept of a government complex, had been erased completely. To members of the National Assembly, the new plan did not seem plausible or possible to expedite smoothly. Exercising leadership of the legislature requires skillful framing of the issue (Neustadt, 1980; Burns and MacGregor, 1984, pp. 30-34). The proponents of the revised plan, however, had a closed mindset that would not consider moving even a single government office in the name of administrative efficiency. This was not a skillful way of persuading politicians who had already showed their strong support for relocation of government agencies into the city.

The new plan clearly offered a potential growth engine for the city and compensated for weak points in the original plan with diverse policy tools, such as a variety of incentives. But the changed plan met with strong opposition from Chung-cheong residents. While the majority of the people nationwide showed accent to the new plan, the majority of Chung-cheong residents favored the original plan. Incentives for industrial investment in Sejong City could take away opportunities from other provinces and other innovation cities that are under construction. This possibility has contributed to reducing general support nationwide. The prime minister tried to foster public support by visiting Chungcheong several times, but he has not found it easy to convince the residents.

The Joint Panel's approach was all-or-nothing and overly hasty. In politics, no one should expect to get all of what they want. US President Ronald Reagan once said, "If you got seventy-five or eighty percent of what you were asking for, I say, you take it and fight for the rest later" (Strock, 1998, p. 70). Although the Korean president has a more dominant political position in the nation than the American president, an abrupt 
policy shift without prudent consultation with the legislature is not likely to succeed.

With the revised plan, the government was able to persuade the conservative part of the populace and succeeded in getting more than 50 percent of support nationwide during the early phase. Many people who were worried about the self-sufficiency of Sejong City welcomed the prime minister's announcement that he would devise a new plan that would promote both regional and national interests to the highest degree. Even during the conflict over revision, residents in metropolitan Seoul and other areas remained relatively supportive. But the revision invoked the same controversial issues that were raised when the idea was first proposed, such as division of the capitol, administrative efficiency, and effects on decentralization. Even within the ruling party, the Joint Panel was not able to form a coalition to support its proposal.

\section{Resonance}

Resonance concerns the affective component of human mind. A proposal resonates to the extent that it feels right to an individual, seems to fit the current situation, and convinces the person that further considerations are superfluous. Resonance often comes about because one feels a relation to a mind-changer, finds that person reliable, or respects that person (Gardner, 2004, p. 16). As a former president of Seoul National University, and an economist, the prime minister tried to exercise a high level of leadership with honest and heartfelt sentiments. He was committed to advocating the merits of the new plan.

The prime minister's authority gave him the power to command attention from politicians as well as the public, and the fact that he was born in Chung-cheong Province gave him credibility. He made a good public display of his intentions and found many cameras whirring about him during press conferences on the revision plan. Major daily newspapers and radio and television stations covered the revision plan, and the issue emerged as the top priority on the national agenda.

Attention is the currency of leadership (Heifetz, 1994, p. 113). But attention should be backed up by assets such as a political power base, popularity, and cohesive force. There should have been extensive preparation before announcing the policy; the prime minister should have kept contact with influential players before the announcement and let them voice their opinions, in order to expand the coalition supporting the plan and deepen its cohesion. But he was not a seasoned politician or a talented political communicator who exuded credibility during the early phase of his tenure. He announced a policy change without first making a serious consensus-building effort, including consultation with ruling party leaders. A leader should move in concert with political allies, not alone, and should go to considerable lengths to network (Mintrom \& Vergara, 1996). 
When transforming a situation, the leader needs an array of supporters in many areas as well as political and institutional resources. The prime minister seemed to succeed in the initial stage in rallying people who had doubts about the implementation of the original plan. They naturally created a friendly, cooperative climate of resonant reality, a climate that fostered a positive outlook on the future (Zander \& Zander, 2000, p. 36). Although there have been diverse attempts by the prime minister and an amicable faction in the GNP, who strongly want the success of the president, to get a favorable consensus from party supporters, they could not find effective ways of using dissent as a source of insight and options for further consideration prior to announcing execution of the new plan. They were not able to find appropriate ways to inspire the formal and informal cooperation of local social groups whose support was critical to the success of this policy change under the conditions of a hostile environment (Selznick, 1996, pp. 272-275).

Because the administrative city bill had been passed in the legislative long ago, the prime minister's argument that the original plan would result in a ghost town and a disaster for the nation, and that the plan was defended based on partisan interest rather than the national interest, was treated as a sort of bigotry. Former GNP chairwoman Park Geun-hye and her faction were unyielding in their attitude toward the original plan. She had been the leader of the GNP, then the opposition party, when the progressive government party passed the administrative city bill; some GNP lawmakers voted in favor of it, although she abstained. And the opposition parties opposed this notion stoutly. Park's followers argued that it was a promise to the nation, especially to Chung-cheong residents.

Park once said that all of the decentralization policies so far had turned out to be failures, but that Sejong City would cause a paradigm shift. Changing position and pushing a new plan would be a tough political decision for Park's faction, because they respected her for placing top priority on keeping her promise. She implied that no one can lead a nation with trust to keep the promise only. The media transformed the issue into a confrontation between "the national interest" and "trust," diminishing the possibility of compromise. While it was beyond the prime minister's influence to play down the symbolic implications of the issue, rhetorical hot air was generated by opposition groups. The prime minister was not able to ensure that the issues would be debated in terms of efficiency of government, regional economic development, science, and technological innovation.

Also, the widespread belief that the prime minister would be a potential competitor in the upcoming presidential election might have given Park's faction an impetus to oppose him. That was one of the reasons his new plan evoked instantaneous revolt from that faction. Some political observers predicted that Park would benefit from the 
revision battle because the residents of the region would stand behind her and ultimately support her in the coming election. The pattern of offer, response, and counterresponse, which is common in politically adversary situations, has not been observed; rather, it has been a single-shot game without the dynamism of a sequential pattern.

In a nationwide survey in the early stage, respondents favoring the revision plan outnumbered those who favored the original plan. In the Chung-cheong region, however, most residents later firmly opposed the revision plan. In the context of a weak associational culture, the divided opinion in the region, and the resignation of Governor Lee Wan-gu in protest against the revision policy, the maneuvering room for the prime minister as policy changer was very restricted. He emphasized that the new plan contained a powerful vision, but that sentiment was not communicated well or shared by opposing groups in the region.

\section{Representational Redescription}

A change of mind becomes convincing to the extent that it lends itself to representation in a number of different forms that reinforce one another. The factors in this include broader aspects of the lever that changes the minds of the attentive audience and the general public. In order to affect the minds of a large and diverse citizenry, leaders must depend heavily on diverse representations of the revised plan and a central message, not to mention their personal background and character. A compelling story about a new vision of change should be embedded in the leader's life. Leaders should find simple ways to promote their ideas based on their own stories and life experiences in order to relate to diverse constituents' minds.

The general outline of the city construction plan, however, could not be changed fundamentally, because the land was acquired and there was little room to change the basic configuration of the city. The site had already undergone leveling and grading. The fact that the prime minister's hometown is in Chung-cheong Province could not help him to exercise the leadership needed to persuade the residents. On the contrary, the resignation of the governor in December 2009, protesting the revision, intensified residents' opposition.

President Lee was the mayor of Seoul when former President Rho proposed movement of the capitol city and later formulated the Sejong City plan. Lee opposed that agenda. Although he agreed to the administrative city plan during his presidential campaign, he confessed, just before the prime minister opened the discussion on the revision plan, that he was ashamed of this compromise. For two years after his inauguration, he did not try to develop alternatives or deepen a political coalition. This did not help accustom people to a revised (redescriptive) model for Sejong City. 
The prime minister was not known for siding with the president, but taking a positive attitude toward revising the Sejong City plan, even before the formal appointment, created confusion. He had said in 2004 that the city should be built as a location for the capital of a unified Korea. The prime minister had often criticized the Lee government's policies, such as the tax cut and the cross-country canal project. But he accepted the president's offer, helping the president to initiate a centrist-pragmatist policy direction. Also the press pointed out that the appointment was a winning card for the president as it could serve as a check on his intraparty rival, Park Geun-hye.

In addition, the fact that the prime minister was born in Chung-cheong Province initially made people listen to him, although his background did not prove politically helpful because he had not formed a solid support base in his home town. The fact that he was an economist lent credibility to his policy orientation toward a more marketfriendly revision of the city plan. If there had been a neutral plan, involving relocation of several government agencies as well as additional investments by industry, then room for exercising leadership could have been expanded, and could have led to a change of mind by opposition groups and diverse constituents.

\section{Resources and Rewards}

While politics is partly about ideas, it is also about the accumulation and deployment of resources. Rewarding and disciplining are explicit tools of transaction leadership (Burns, 1978). Mind change is more likely to occur when considerable resources can be devoted to the issue. Sanctions or discipline, which is the other side of rewards, are also useful in selling a policy or negotiating, even from a position of strength. In order to pass a bill in the legislature, a leader must expand the core support base and possibilities of acceptance by conferring various resources, such as economic benefits, power, prestige, budget, and position. A leader must offer potential followers a set of benefits, some of these potential followers must be willing to buy, and the followers must continue to expect a net gain (Moe, 1980, pp. 38-39).

Policies are, in a sense, nothing more than vehicles for the distribution of benefits to groups of constituents. The residents were interested in a new package of policy benefits that would be delivered to them. The new plan has offered special incentiveslow land prices and tax reduction - to prospective investors; many large firms showed interest in investing, and two universities intended to move in. Also, a major project for a global science belt, which includes a convergence-complex basic science center, an accelerator, and an advanced international science school, were planned for the western side of the city.

In the province, residents' opinions have been divided. Proponents argued that in 
decades, Sejong City would become a mecca for science and technology firms, with a population of about 500,000, and the total investment would be 18 trillion won by 2020 , creating 250,000 jobs. The new plan calls for the completion of the city by 2020 , 10 years earlier than called for in the original plan. But it did not convey the tangible benefits to all residents. More than half of the Chung-cheong residents seemed not to be satisfied with the additional benefits the new plan would bring. They were most united on having a single plank of multifunctional administrative town.

In addition, unlike in a general election or presidential popularity (Heinz \& Lewis, 1985), specific policy benefits had far more influence than probable future welfare of the residents (Stone, 2002, pp. 210-230). Several other provinces, such as Kyungbuk and Jeonnam, were worried about losing potential benefits if the plan was not revised; residents of other provinces were worried about benefits they might lose if the plan was revised. They argued that changing the plan in a way that serves certain regions at the expense of others is not responsible leadership. People who were concerned about efficiency or the general state of the economy and its likely rate of progress did not seem to be effectively organized to support the government, although the benefits of the new plan were significant.

The president said in August 2009 that he would have little to gain politically, and predicted that the revision would cost him much of his political capital. When the GNP supported the original plan, the political calculation turned out to be favorable. With local elections coming up in 2006, the GNP, a minority party at the time, found itself in a bind. Party leaders worried that tenacious opposition would cost them votes in the swing region, without being able to stop the plan in the National Assembly. Some GNP lawmakers voted yes when the original city bill passed. Therefore, the Park Geun-hae faction had to find additional benefits to revert their attitude. Park's faction did not perceive additional net benefits from the revision; they would lose their reputation for political principle.

The president as well as the prime minister had difficulty finding resources to help coax the members of Park's faction into supporting the revision. The Liberal Forward Party, based in the Chung-cheong region, would lose its power base if the new bill passed. They led the opposition and attacked the government, exploiting a divided public opinion. Other opposition parties attacked the government for not keeping the political faith because they would be losers, too, if the bill passed.

\section{Real-World Events}

An effective leader has to move beyond individual incentives to the development of cooperation and trust. A significant event or an unwavering fact affects many indi- 
viduals who are contemplating a mind change for cooperation and trust. Foreign as well as domestic examples of location of government facilities encourage a change of mind. A similar case in Germany years ago (moving the capital from Bonn to Berlin) was presented as a bad example, and that also raised disputes and did not help the government's position. The domestic case of the Daejeon government building also did not succeed in making a spark in the fireplace of political vortex. The advantages and disadvantages of the administrative office separation cannot be measured systematically for everyone to agree upon, and the background behind the separation is complicated and thus difficult to address conclusively. Tedious arguments for and against the separation emerged once again, and no new decisive blow was made on either side. No additional hard evidence emerged that the city could not be self-sufficient.

The Daejeon administrative complex, established in 1988 near the new town, took more than 10 years before the rate of officials living in Daejeon with their families surpassed 60 percent, and it seemed that the future of Sejong City might be little different. Surveys showed that less than half of the affected public officials would migrate to the provincial town with their families. The poor residential and educational environment of the new town could not induce enough prospective residents to move into the city. Those arguments and facts, however, did not change most people's minds; most continued to support the original concept of a multifunctional administrative city.

Local elections held on June 2, 2010, could have been an opportunity to gain momentum in persuasion. Sejong City was a high priority in this election, along with free lunches for school children, four major river projects, and the response to the Cheonan sinking (Chosun Daily, May 13, 2010; Kyunghyang Daily, May 27, 2010). But the ruling party experienced stunning setbacks in this election, losing all three local governors' positions in the Chung-cheong area. The government is no longer advocating the revision plan; the fate of the city has fallen into the National Assembly's hands. Major investors have begun to rethink their earlier commitments. The nation had to go back to square one. There were no winners except the vehement opposition groups: the prime minister, the government, the ruling party, and the people have all become losers.

\section{Resistance}

Mind changing is unlikely to happen when resistance is strong, the policy entrepreneur is not able to find an effective way to reduce it, and the five other factors described above do not point strongly toward change. Building a new coalition and skillfully managing conflict was essential to overcome resistance (Burns, 2003, pp. 120-136) The expansion of a support base within the governing party was essential to restore vitality to efforts to transform the equilibrium that had been hardening during 
the two years since the inauguration of the new president. The prime minister as well as the president should find means to tilt the balance of existing factions within the GNP and fend off the serious threat to their political leadership.

The GNP provided an optimal environment for the new prime minister's possible pursuit of the presidency in 2012, compared to the previous contenders who joined the presidential race. To the prime minister, revision of the Sejong City plan was a good chance stand for jump on the contention, but he faced considerable resistance at the beginning of his pursuit of the Sejong City plan revision. The Park faction criticized his revision efforts with a fine sense of political timing. They perceived that the appearance of the prime minster as a major actor on the political scene, and his success in revising the Sejong City plan, would make him a strong competitor to Park in the next presidential election. Therefore they took a stand against the revision from the beginning. They did not try to adjust their position, because they understood that presenting a solid opposition would pay off politically.

The Liberal Forward Party, as mentioned above, could not take even one step back from their original position because if they did so, their power base would collapse. The other opposition parties, whose platform depended on execution of the original plan, took advantage of the region's tense atmosphere in the local elections and residents' cohesive opposition groups. The size and density of the opposition coalition never dwindled, and their forces have remained united against the prime minister. They were unanimous in their hatred for the group that led the revision plan and continuously mobilized and spearheaded the opposition.

The prime minister has attempted to appeal to the public directly in order to put more pressure on the opposition groups (Kernell, 1986), but the resistance from residents of Chung-cheong Province hindered him from carrying out this approach and eventually defeated him. They cast doubt on his credibility, and he faced a crisis in leadership. The prevailing resistance, which was hardened by political calculation, could not be overcome in a short period of time by a new political conscript.

\section{FINDINGS AND CONCLUSION}

\section{Importance of Process and Structure in Policy Leadership}

Prime Minister Chung Un-chan resigned on July 29, 2010, taking responsibility for "prompting concerns and disputes" nationwide over his failed attempt to revise the Sejong City plan. From the beginning, he was observed to be too hasty and reckless in his push to change the plan. Before his inauguration, he had voiced his resolution to 
advocate for revision. He too quickly adopted a conclusive plan for revision rather than opening up a forum for discussion and deliberation-a very volatile political course. Process management of leadership activities should have been well prepared; instead, he rapidly attempted to exercise leadership as soon as he took office, without first attempting to cultivate a reputation.

He should have found creative ways of pushing the politically sensitive revision issue, by modulating surrounding structures. His diagnosis of the issue and the situation was criticized as not accurate. Nor was he assisted in his deliberation and decisionmaking in this politically adversary situation by high-ranking government officials and potential allies. How well such a bid succeeds depends on how the situation is structured so as to convince others to support it, and how the policy debate unfolds.

It was not easy to find any collective character of the process of leadership when the revised plan was pronounced. The prime minister needed strategies for expanding his advocacy coalition and presenting the proposal in a convincing way, further building national consensus by uniting a diverse populace in a positive response. Using only one mind-changing lever, rational argumentation, which has repeatedly divided groups without conclusion, he lacked the power to change the minds of key actors and the general population.

The qualities that make for effective mobilization of support are not always combined in one and the same person with those that are requisite for devising policy. Thorough knowledge of incentives, political cleavages, and levels of resistance is, for a political leader, the first step toward the construction of alliances. But using that knowledge to mobilize support is quite a different task. Although electoral support for the president was strong, top-level policy leadership that strategically used persuasion and bargaining in order to create a coalition out of separate interests (Weatherford, 2009, pp. 538-539) was indispensible in the case of the Sejong City plan. Inability to create a strong coalition in support of revision was a serious liability.

Effective policy leadership cannot be exercised in the context of divisions between the central government and localities and unfavorable political cleavages within the governing party. Disjointed institutional structure in the government and ruling party hinders portrayals of abrupt policy change. In addition, when social groups outside of the government are divided, with regional benefit lines and opposing groups exploiting political wiles, exercise of entrepreneurial policy change leadership is difficult; each measure ("lever") for changing the minds of politicians and constituents fails to work effectively and will be vulnerable to a counterattack by well-organized opponents.

Institutional trust-building and the degree of legitimacy enjoyed by the government (Fuchs, 2010, pp. 69-70) are important. From a short-term perspective, it is a priority task for a policy entrepreneur to build and enhance trust within the ruling camp in 
order to make a sudden policy change. From a long-term perspective, enhancing state legitimacy is still a fundamental task for elite groups to adapt policy flexibly.

\section{Reflection on Changing Minds}

This paradigm of changing minds, based on cognitive theory, explains leadership effectiveness to a large extent. It is well understood that the political process is a psychological process of feelings and persuasion (Laswell, 1960, pp. 74-76; Neustadt, 1960, pp. 9-10). Some modifications or adjustments, however, can be made when we deal with the case in point, without damaging the theoretical basis adopted from Gardner. In this case, the reason and research levers, which Gardner presents as separate, have been integrated into one lever, rational argumentation, for the sake of simplicity. ${ }^{1}$

At the same time, the resistance lever should be more carefully scrutinized when analyzing the case of a failure to bring about change caused by the existence of strong opposition groups or an adversary political situation. Originally, this lever dealt with managing resistance and reducing the resistance aspect of changing minds. But here, it seemed almost natural to see a tendency to maintain the status quo or resist change in analyzing every single lever. This author went further and thought that each of the five levers has two facets: one change inducing, the other change rejecting. If the changerejecting aspects of the five levers are stronger than the change-inducing aspects, leaders cannot succeed in changing minds or behaviors (Jogulu, 2010, p. 715). In this case, the negative side or change-rejecting tendency in the levers of resonance, representation, resources and rewards, and real-world events, but not rational argument, was analyzed accordingly.

Furthermore, when a constituted (formal or positional) leader starts to enter a political stage with limited tenure, the process aspect of leadership must be emphasized and carefully scrutinized. Leadership activation should take time, and process management of the leadership task as well as initiation of leadership is crucial, especially for a transformational leader. From a process perspective, leadership involves three sequential tasks: (1) diagnosing the situation authoritatively, (2) devising a course of action to resolve the problem, and (3) mobilizing political support (Tucker 1995, pp. 31-34). The way of carrying out the leadership function of signalizing is very important. Communication, persuasion, and mobilization take time. And the sequence of activities is

1. The research lever presented by Gardner contains much broader aspects of leadership, including institutional environment, target groups, and social atmosphere; but in this case, the author could not trace all the research activities and limited the focus to rational analysis of the situation and devising a new plan. 
crucial in structuring a situation and building a community's support for a prescribed policy response, because the activities of persuasion and mobilization of support are different from those of rationally designing a new plan.

In this case, the prime minister carried out the diagnosing and signalizing functions in a decisive manner, and his team seemed to put forth much of their energy in devising a revision plan with the backing of higher leadership. The necessity for leadership to be persuasive arose within the ruling party. Once the whole government, including the ruling party, had been persuaded, it became necessary for leadership to persuade the opposition camp and later the populace. The question in the validity of the definition of the situation and signaling arises in the case, to the worse, the problem of constructing collective infrastructures of leadership is at serious stake. The process of consensus building should be given a great deal of weight whenever the government attempts to change policy in the face of obvious opposition.

Real-world events are very important for persuading key politicians and the public to change their minds. In this case, it appears to have been difficult to change minds when publically known principles were strongly held by a powerful politician. It is all the more difficult when a dense oligarchical atmosphere surrounds a luminous political figure who opposes policy change. Also, resistance could not be overcome without changing the political structure. In this sense, the analytical framework applied here works effectively in explaining the failure of policy change in this case.

This framework, rooted in historical streams of psychological theory, emphasizes behavior. At the same time, it has a strong focus on cognition (Sims \& Lorenzi, 1992, pp. 285-305). Policy management is both a behavioral and a cognitive issue. This case analysis has demonstrated a close relationship between cognitive theory and policy theory, which should be integrated into policy leadership studies.

\section{REFERENCES}

Burns, J. M. 1978. Leadership. New York: Harper. 1984. The power to lead. New York: Simon \& Schuster.

Chosun Daily, May 13, 2010.

Fuchs, F. 2010. Historical legacies, institutional change, and policy leadership. Theory and Society, 39(1): 69-107.

Gardner, H. 2004. Changing minds. Boston: Harvard Business School Press.

Heifetz, R. A. 1994. Leadership without easy answers. Cambridge, MA: The Belknap Press of Harvard University.

Heinz, E., \& Lewis- Beck, M. (eds.). 1985. Economic conditions and electoral out- 
comes. New York: Agathon.

James, L., et. al., 1999. Punctuated-equilibrium theory. In P. A. Sabatier (ed.), Theories of the policy process. Westview Press.

Jogulu, U. D. 2010. Culturally-linked leadership styles. Leadership and Organizational Development Journal, 31(8).

Jones, B. D (ed.). 1989. Leadership and politics. Lawrence: University Press of Kansas.

Kernell, S. 1986. Going public: New strategies of presidential leadership. Washington, DC: Congressional Quarterly.

Kyunghyang Daily, May 27, 2010

Laswell, H. D. 1960. Psychopathology and politics (rev. ed.). New York: Viking Press.

Mintrom, M., \& Vergara, S. 1996. Advocacy coalitions, policy entrepreneurs, and policy change. Policy Studies Journal, 24(3): 420-434.

Moe, T. 1980. The organization of interests. Chicago: University of Chicago Press.

Neustadt, R. E. 1960. Presidential power: The politics of leadership. New York: Wiley. 1980. Presidential power: The politics of leadership from FDR to Carter. New York: Wiley.

Office of the Prime Minister. 2010. White paper: Sejong city revision, the panel. Seoul: The Prime Minister's Office.

Selznick, P. 1996. Institutionalism "old" and "new." Administrative Science Quarterly, 41: 270-277.

Sims, H. P., Jr., \& Lorenzi, P. 1992. The new leadership paradigm. London: Sage.

Stone, D. 2002. Policy paradox: The art of political decision making. New York: Norton.

Strock, J. M. 1998. Reagan on leadership. Rocklin, CA: Prima Publishing.

Tucker, R. C. 1995. Politics as leadership. Columbia: University of Missouri Press.

Weatherford, M. S. 2009. Comparing presidents' economic policy leadership. Perspective on Politics, 7(3).

Zander, R. S., \& Zander, B. 2000. The art of possibility: Transforming (in Korean). Boston: Harvard Business School Press. 